\title{
THE MEANING OF DISPOSSESSION
}

\author{
JILL FRALEY*
}

\begin{abstract}
This article critiques our focus on possession as the cornerstone of theories of property, examining the limitations of possession both as a theoretical concept and as a practical one. Second, the article examines how an investment-based labor approach has sharply shaped our understandings of possession. By examining the intertwining of possession and labor during colonization, the article describes how the labor approach to possession excluded more communal corollaries and instilled in American property law a consistent push toward grounding land claims at the labor-possession nexus.

Re-thinking the labor-possession nexus yields important shifts. First, labor matters for reasons other than investment-backed expectations. Labor matters because the loss of investments often means violence. There is a reason for the historical correlation between changes in property rights and revolutions. Focusing investment critically places property as a first-order value when it is, in fact, a second-order value or a means to a social end (specifically, non-violence). Second, focusing on labor as investment also places such an extraordinary emphasis on possession that American scholars and courts rarely think much about dispossession. Our emphasis on possession rather than dispossession frames American property law in terms of vested rights to such a degree that while scholars may think in terms of social relations theories, American property law is stuck thinking in terms of individual ownership rights even when the courts acknowledge the social nature of property arrangements.
\end{abstract}

\section{INTRODUCTION}

Property is a first-order business. ${ }^{1}$ From overhead bins and elbow room on airplanes ${ }^{2}$ to law student carrels, ${ }^{3}$ from sibling scuffles ${ }^{4}$ to the phantom boarder

* Jill Fraley, Associate Professor of Law, Director, Center for Law \& History, Washington and Lee University School of Law. The author is grateful for the comments and suggestions of William Boyd, Ann Carlson, Stephen Gardiner, Carmen Gonzalez, Blake Hudson, Sarah Krakoff, Jessica Owley, Jed Purdy, James Salzman, Mark S. Squillace, David Takacs, and Buzz Thompson. I also thank the faculty of the University of Texas at Austin School of Law, where I presented this paper in the faculty workshop.

1. Or, as John Sanders has observed, "Any political theory, any economic theory, any ethical theory — perhaps any theory whatsoever that deals with human behavior, whether individual or social - is likely to have something to say about property.” John T. Sanders, Justice and the Initial Acquisition of Property, 10 Harv. J.L. \& PuB. PoL'y 367, 367 (1987).

2. Christopher Elliott, Plane Etiquette 101, NAT'L GeOGraphiC Traveler (Apr. 29, 2013), http://www.intelligenttravel.nationalgeographic.com/2013/04/29/plane-etiquette-101/ [https://perma.cc/MLG2-YR2A].

3. Carrels have provided enough contentious debates in the past that many schools now use a lottery system to distribute carrels. See, e.g., Pence Law Library Carrel Policy, Am. U. WASH. 
syndrome that so frequently haunts the elderly, ${ }^{5}$ ordinary citizens obsess over property on a daily basis. Theorists, on the other hand, obsess over possession. ${ }^{6}$

Theories of property tend to focus on possession and to seek creation stories that explain the prevalence of first possession rules across cultures. This article questions that emphasis on first possession as the key moment for theorizing property and instead suggests that to the degree that we acknowledge the social nature of property arrangements, the key moment may come at the moment of dispossession - the moment that the second person attempts to take or use the property. $^{7}$

Cross-culturally, most children's fights involve property, ${ }^{8}$ as do most delusions of the elderly ${ }^{9}$ suggesting the primal role of property in both our sense of self and sense of security. We not only have the fundamental need for property that Carol Rose recognizes in her theory of personhood, ${ }^{10}$ but also a foundational fear of dispossession. Dispossession is worth theorizing in property law and we largely have not done so.

The article proceeds along these lines: First, the article examines our reliance on the concept of possession and critiques that reliance, describing our many theoretical and practical difficulties in creating a settled definition. The failure of possession to yield a concrete and clear idea makes the concept vulnerable to serving as a proxy for something else, namely investments via labor.

CoLL. L., (Aug. 2015), http://library.wcl.american.edu/carrel/ [https://perma.cc/8R33-5YZW] (providing the parameters of the library's lottery system). Other schools lend carrels to students on a daily basis only. See, e.g., Law Library Carrels, U. BuFf., http://law.lib.buffalo.edu/aud/carrels. asp [https://perma.cc/JW8D-LDBT] (last visited Jan. 2, 2017).

4. Sibling fights typically involve either possessions or the right to use (or to exclude from) a particular space. See Solving Sibling Squabbles, Better Homes \& GARDEns, http://www.bhg. $\mathrm{com} /$ health-family/parenting-skills/when-kids-act-up/solving-sibling-squabbles/ [https://perma.cc/86QH-7DSM] (last visited Jan. 2, 2017) ("Sibling fights are often about possessions or territory."). With that said, perhaps children also demonstrate the primacy of property rules in any civilization: To my amusement a colleague (not a property professor) recently explained that his two children established a system of government for their bedrooms and play area. They first began, naturally, by creating a system of property rules. See also Donald J. Kochan, I Share, Therefore It's Mine, 51 U. RICH. L. REV. (forthcoming May 2017) (discussing children's fights and the psychology of property ownership), https://papers.ssrn.com/sol3/papers2.cfm? abstract_id=2820456 [https://perma.cc/LR5T-QQW7] (last visited Feb. 24, 2017).

5. Phantom boarder syndrome refers to a common delusion of an intruder within one's home. "Delusion of theft and phantom intruder delusion are among the most frequent delusions in dementia." Seishi Terada et al., Delusion of Theft and Phantom Intruder Delusion in Demented Elderly Patients in Japan, 18 J. Geriatric Psychiatry \& Neurology 142, 142 (2005).

6. Virtually all property course books begin with the idea of possession as the root of title. Joseph William Singer, Starting Property, 46 ST. LouIs U. L.J. 565, 566 (2002).

7. See infra Part II.

8. See Solving Sibling Squabbles, supra note 4.

9. Terada et al., supra note 5.

10. See generally Margaret J. Radin, Property and Personhood, 34 StAN. L. REV. 947 (1982). 
Next, the article engages the colonial history of the concept of possession to demonstrate how labor became so strongly tied into the American idea of possession. The article considers the investment-based labor approach and discusses how that approach morphed into a common law concept of possession that relied upon, but was rather untrue to, Locke's theories.

Notably, one of the greatest points of departure between the American possession-labor nexus and Locke's approach is the full emphasis on possession and the neglect of the corollary of dispossession. The article proceeds by considering how focusing on dispossession rather than possession would yield a different approach to property theory.

\section{The Cornerstone of Possession}

Within the common law, possession stands as the "origin of property."11 Grounded in principles of Roman law, which favored possession substantially, ${ }^{12}$ the pairing of property and possession solidified during the colonial period as competing European powers challenged each other to articulate grounds for legal title to foreign territories. Indeed, the colonial enterprise may have woven deeply into the labor aspects of Locke's theories of property, which were attuned to the particular problems of claiming property in colonial lands. ${ }^{13}$

When it came to territorial claims of European powers vis-à-vis each other, understandings of possession evolved as competing colonial powers articulated legal arguments that were consistent with their own legal cultures. ${ }^{14}$ Thus, rather than cohering neatly in a single procedure, land claiming resembled a boisterous

11. Carol M. Rose, Property \& Persuasion: Essays on the History, Theory, and RHETORIC OF OWNERSHIP 12 (1994). Initial acquisition of property is a central preoccupation of theorists because any theory of property must ground itself in some account of how initial rights were acquired from the great primordial commons. See Sanders, supra note 1, at 368-69.

12. Under Roman law, land had to be continuously possessed lest another begin occupancy: quod nullius est, fit occupantis. 1 JOHN ERSKINE, AN INSTITUTE OF THE LAW OF SCOTLAND 223 (1824). The Roman approach emphasized labor, focusing on a system of property ownership that maximized utility. See Brian Gardiner, Squatters' Rights and Adverse Possession: A Search for Equitable Application of Property Laws, 8 IND. INT'L \& COMP. L. REV. 119, 124-25 (1997). Possession effectively claimed not only "things which had not as yet fallen under the power of any proprietor but [also] those which had been lost or relinquished by the former owner." 1 ERSKINE, supra. Notably, however, Roman law limited each person to the land he could cultivate himself, thus distributing land broadly throughout the community. Gardiner, supra, at 125.

13. See Barbara Arneil, John Locke and America: the Defence of English COLONIALISM 2 (1996) (arguing that the role of America and indigenous land has been neglected by scholars). Locke, in fact, repeatedly uses North America as an example when he discusses his theory of property. Id. at 110, 141 .

14. See generally Patricia Seed, Ceremonies of Possession in Europe's Conquest of THE NEW WORLD 1492-1640 (1995) (demonstrating how different European cultures including the French, British, and Spanish recognized different legal methods of claiming land, consistent with their own individual cultures). 
gridlock of competing forms, including ceremony, ${ }^{15}$ discovery, ${ }^{16}$ conquest,${ }^{17}$ and cultivation ${ }^{18}$ - the British favorite. ${ }^{19}$

More than mere physical occupation, the British approach required the labors of planting or cultivation. ${ }^{20}$ Thus, when discussing African colonies, Vinogradoff summarized the British approach as holding that not just "occupancy" was required but, specifically, occupation "for purposes of cultivation ... [which] gives rise to a possessory right." ${ }^{21}$ Hedging no bets, Grotius declared that "uncultivated land ought not to be considered as occupied."22

British writers contrasted their settlements as "actual possessions" against the more imaginative or "paper" possessions claimed by Spain and Portugal by virtue of Papal proclamations. ${ }^{23}$ British writers scoffed at Spain's focus on the mining

15. Edmund Burke in his account of colonization describes that Columbus "was to take possession of the island in the name of their Catholic majesties, by setting up a cross upon the shore," which he did with "great multitudes of the inhabitants looking on, ignorant and unconcerned at a ceremony which was to deprive them of their natural liberty." EDMUND BURKE, An Account of the European Settlements in America 11, § 1 (1777).

16. British writers carefully claimed that their settlements were made "upon a place never before possessed by the Spaniards." David Jones, The Life of William III, Late King of ENGLAND ANd Prince of Orange 530 (1703).

17. Even where claimed by other Christian nation states, conquest was claimed to open land for possession and title by the takers. Thus, an early colonist could write of the "glorious conquests and acquisition of the Island of Martinico." 6 William Laurence Saunders, The Colonial RECORDS OF NORTH CAROLINA 803 (1888). Conquest was, of course, a rather terrible justification for title in the colonial process, because it suggested that, at least in some circumstances, property could be taken from first possessors "against their will." Singer, supra note 6, at 567.

18. See SEED, supra note 14, at 26-27 and accompanying text.

19. For example, Pennsylvania's charter granted the right to claim land "not yet cultivated and planted." Charter for the Province of Pennsylvania - 1681, Avalon ProjeCt: YAle L. SCH., http://avalon.law.yale.edu/17th_century/pa01.asp [https://perma.cc/36NR-62F3] (last visited Jan. 2, 2017).

Laura Brace argues that the idea of cultivation and land "improvement" has centrally affected "attitudes towards property and ownership." Laura Brace, Husbanding the Earth and Hedging out the Poor, in LAND AND FreEdom: Law, Property Rights, AND the British DiAspora 5 (A.R. Buck et al. eds., 2001).

20. See SEED, supra note 14, at 26-27. Without religious and racial components, the basic legitimacy of claiming empty territory continues in international law. Unoccupied land without an indigenous people appears to be available to first possessors, perhaps even when those claimants are not sponsored by any nation-state (at least so far as property, not sovereignty or jurisdiction, would be concerned). See L. Benjamin Ederington, Property as a Natural Institution: The Separation of Property from Sovereignty in International Law, 13 Am. U. INT'L L. REV. 263, 26566 (1997) ("Despite the absence of a state sovereign to give legal sanction to these rights, customary practice nonetheless has repeatedly recognized private property rights in terra nullius.").

21. Paul Vinogradoff, The Growth of the Manor 80 (1905).

22. 2 Grotius, LaW of WAR ANd PeAce 202 (1625).

23. For an example of explanations of actual possession, see J.D. CHAMBers, 
of gold and silver rather than planting, "looking with a just disdain upon this gilded majesty of Spain and knowing well that Empire must decline [those] whose chief support and sinews are of coin." 24

Following the same pattern as colonial land claiming, legal accounts of the origins of property in the colonial era similarly center on possession. Blackstone believed that "occupancy is the thing by which the title was in fact originally gained." 25 Writing in 1689, John Locke explained that "whatsoever he tilled and reaped, laid up and made use of, before it spoiled, that was his peculiar right." 26 The common thread across the genre was the centrality of narratives of first possession.

Such a focus on first possession is, perhaps, to be expected. Sugden, following Hume, has suggested that a "rule favouring possessors has a natural prominence. ${ }^{, 27}$ And, indeed, first possession rules oddly unite a variety of legal schemes across the broadest range of cultures, from Native American to African, Western Civil to Islamic Law, ${ }^{28}$ and across a wide variety of property rights from minerals to water. ${ }^{29}$ Apparently, even in prehistory, first occupation of a parcel

Nottinghamshire in the Eighteenth Century: A Study of Life and Labour Under the SQUIREARCHY 140 (2d ed. 1966). The papal declarations were rejected paper pronouncements to the British. James Horn, The Conquest of Eden: Possession and Dominion in Early Virginia, in ENVISIONING AN ENGLISH EMPIRE 25 (Robert Applebaum \& John Wood Sweet eds., 2005). British theorists explained that "in these large countries of America, it were capricious to require the actual possession of every particular place," but still attempted to limit Spain, reasoning that "when the Spaniards begun to plant there, they could only by their possession have appropriated as far as they did possess." JONES, supra note 16, at 531.

24. Robert Burton, The English empire in America or, A VieW OF THE DOMinions of the Crown of England in the West-Indies. ... With an aCCOUNT of the Discovery, SITUATION, PRODUCT, ... OF THESE COUNTRIES. TO WHICH IS PREFIXED, A RELATION OF THE FIRST DISCOVERY OF THE NEW WORLD CALLED AMERICA BY THE SPANIARDS. ... ILLUSTRATED WITH MAPS AND PICTURES 189 (1728).

25. 2 William Blackstone, Commentaries, reprinted in Perspectives on Property LAW 45, 51 (Robert C. Ellickson et al. eds., 3d ed. 2002).

26. John Locke, Two Treatises of Government 193-94 (1689).

27. Robert Sugden, The Economics of Rights, Cooperation and Welfare, in PERSPECTIVESON Property LAw, supra note 25, at 174.

28. Richard A. Epstein, Property as a Fundamental Civil Right, 29 CAL. W.L. REv. 187, 190 (1992). For specific examples, see Jacob H. Beekhuis, Civil Law, in InTERnAtional ENCYClopedia of Comparative Law (1975) (on civil law); KARL N. Llewellyn \& E. AdAmson Hoebel, The Cheyenne Way: Conflict and Case Law in Primitive Jurisprudence (1941) (on Native American law, the Cheyenne Tribe); J. Norman D. Anderson, Islamic Law, in International Encyclopedia of Comparative LAw (1975); Kwamena Bentsi-Enchill, The Traditional Legal Systems of Africa, in InTERNATIONAL EnCyClopedia of COMPARATIVE LAW (1975). For a summary, see James R. Rasband, Questioning the Rule of Capture Metaphor for Nineteenth Century Public Land Law, 35 ENVT'L L. 1005, 1012 (2005).

29. See Rasband, supra note 28 ("To label nineteenth century public land and natural resource laws as rules of first possession is, perhaps, more accurate than labeling them as rules of 
of land generated a right of ownership. ${ }^{30}$

For modern legal theory, first possession remains the dominant method of initially allocating real property. ${ }^{31}$ Even those who criticize this approach tend to acknowledge the natural prominence of first possession rules. For example, Epstein has argued that there is no moral justification for first possession rules, even while acknowledging the strong practical and intuitive appeal of such rules. ${ }^{32}$ Indeed, his very cogent argument against a moral justification for first possession rules possibly makes all the more clear their intuitive appeal.

\section{FAILURES OF POSSESSION}

Yet, for all the centrality of possession, both historically and theoretically, possession as a concept and practical matter proves remarkably difficult to pin down. We have invented a host of subordinate conceptions such as actual, real, and constructive possession, which are supposed to clarify the core idea, and yet we still struggle to conceptualize and implement possession within everyday case law.

One reason for the difficulty is simple: Real property is never truly possessed, at least not in the same sense that one naturally holds an object. At any one time, a person can physically touch a couple of square feet, or perhaps a bit more in interesting yoga poses or a game of Twister.

In case law, "actual" is one of many adjectives placed before possession in an effort to render the concept specific and tangible, when, in fact, the term is used in an imaginative or metaphorical fashion. ${ }^{33}$ Thus, for example, in the famous case of Hammonds v. Central Kentucky Natural Gas Co., the court held that "oil and gas are not the property of any one until reduced to actual possession by extraction." "A Adjectives such as "actual" and "real," when placed before "possession," implicitly acknowledge that possession itself is not enough. Even the "actual possession" so often discussed in Anglo-American case law is not actual. A person's things may occupy land and he may regularly visit or work upon larger portions of the land. He may build his fences, plant his crops, pasture his sheep, or establish a daily patrol. Yet at any given time, he is still limited to the few square feet occupied by his physical body.

Recently, a Massachusetts trial judge nicely framed the problem of possession in a jury instruction, explaining

There are two kinds of possession, actual possession which is this glass

capture.").

30. Richard A. Epstein, Takings: Private Property and the Power of Eminent DOMAIN 10 (1985).

31. See generally Richard A. Epstein, Possession as the Root of Title, 13 GA. L. REV. 1221 (1979); Carol M. Rose, Possession as the Origin of Property, 52 U. CHI. L. REV. 73 (1985).

32. Epstein, supra note 31, at 1234.

33. Jill Fraley, Finding Possession: Labor, Waste, and the Evolution of Property, 39 CAP. U. L. REV. 51, 58 (2011).

34. 75 S.W.2d 204, 205 (Ky. 1934), rev'd, 736 S.W.2d 25 (Ky. 1984). 
case that I have in my hand, or constructive possession which would mean very simply if I had this glass case in a safe at my home, I would constructively possess it even though it is not on my person. ${ }^{35}$

This formulation reduces actual possession to what it is in physical terms-what "I have in my hand," thus emphasizing the metaphorical nature of possession when applied to real property. What the judge did not mention, however, is that his home is just as much constructively possessed as his glass case.

The metaphorical nature of possession of real property becomes most clear when examining cases challenging possession. Because there can be no true physical possession of any significant quantity of land, the courts evaluate possession by looking at the behavior of the parties, particularly their uses of the land. ${ }^{36}$ For example, when attempting to distinguish between statutory uses of the phrases "any possession" and "actual possession," the Court of Appeals of Alabama determined that actual possession describes land "in the immediate occupancy of the owner." ${ }^{37}$

Because possession was being defined in terms of the social actions and land uses of the owners or purported owners, the nature of evidence sought had to be molded to the physical geography. The evidence of possession needed was that "required by the character and situation of the lands" ${ }^{38}$ or, for each jurisdiction, "the circumstances of this country." 39 The evidence required allowed for "the situation of the parties, the size and extent of the land, and the purpose for which it is adapted" $" 40$ or "for such purposes as it is capable." 41

Even occupancy had to be clarified as that which was "an occupancy ... according to its adaptation to use." ${ }^{42}$ The focus of inquiry was on "acts," which could not be "doubtful and equivocal in their character," to create possession. ${ }^{43}$ Actual possession required "subjecting it to the will and dominion of the occupant" and therefore was "evidenced by those things which are essential to its beneficial use." ${ }^{.44}$ As a result, "The usual kind of actual possession relied upon is occupancy, use or residence upon the premises . . . evidenced by cultivation, enclosure, or erection of improvements." 45

35. Commonwealth v. Talbert, No. 09-P-2231, 2011 Mass. App. Unpub. LEXIS 96, at*4 (App. Ct. Jan. 24, 2011).

36. Grogan v. Hillman, 930 So. 2d 520, 523 (Ala. Civ. App. 2005) (citing Moorer v. Macon, 273 Ala. 66 (1960)).

37. Id. (citing Shannon v. Long, 60 So. 273 (Ala. 1912)).

38. Allaire v. Ketcham, 55 N.J. Eq. 168, 170 (1896).

39. Courtney v. Turner, 12 Nev. 345, 352 (1877).

40. Johnston v. Albuquerque, 12 N.M. 20, 28 (1903).

41. State v. Newbury, 29 S.E. 367,368 (N.C. 1898).

42. Morrison v. Kelly, 22 Ill. 609, 624 (1859).

43. $I d$.

44. Courtney, $12 \mathrm{Nev}$. at 352.

45. Quatannens v. Tyrrell, 601 S.E.2d 616, 619-20 (Va. 2004) (citing LaDue v. Currell, 201 Va. 200, 207 (1959)). 
Relying on actions and land use, courts investigating possession incorporate particular social norms about the possession and development of land ${ }^{46}$ Indeed, these preferences have been criticized for privileging industry, and thus labor, while disfavoring conservation efforts, and collective values. ${ }^{47} \mathrm{~W}$ ith possession defined in terms of actions and particular developments and uses of land, simple preservation does not readily provide the expected proofs. ${ }^{48}$

Without asserting that possession of real property is always metaphorical, other scholars have recognized how possession relies upon a series of judicially validated acts. ${ }^{49}$ In Carol Rose's words, the doctrine of first possession's "texts

46. See generally Fraley, supra note 33 (arguing the meaning of possession has evolved with social priorities). Such judicial inquiries typically arise in the context of adverse possession. Notably, possession also fails us as we try to make sense of the conflicting requirements for good faith or mistake in claims of adverse possession. Early U.S. Supreme Court cases, in interpreting various state formulations, regularly suggested that adverse possession was not possible through bad faith - i.e., that a claim must be made "under color of title." Otherwise such claims were simply trespass rather than ouster. Ewing's Lessee v. Burnet, 36 U.S. 41, 52 (1837). Thus, adverse possession generally resulted from "entering peaceably under a void deed, or a void feoffment, or by fraud," where the intent to dispossess was imputed. Jackson ex. dem. Bradstreet v. Huntington, 30 U.S. 402, 439 (1831). The possession was undertaken with "[a] title relied on" and was "strictly adverse to all and every opposing claim, because colorable legal." Harpending v. Reformed Protestant Dutch Church, 41 U.S. 455, 464, 467 (1842). Indeed, "good faith" was a specific requirement in many cases. As the Supreme Court explained in Iowa Railroad Land Co. v. Blumer, if the party proved the elements of adverse possession, then "unless he was acting in bad faith, [the party's actions] would ripen into full title.” 206 U.S. 482, 495 (1907). Yet, outcomes demonstrate that courts remain loathe to allow adverse possession when bad faith is proven, even if good faith is not an explicit element of the jurisdiction's test for adverse possession. See Sprankling, infra note 47.

47. See John G. Sprankling, An Environmental Critique of Adverse Possession, 79 CORNELL L. REV. 816, 817 (1994) (arguing that within adverse possession cases, conserved areas generally lose against industrial developments of land).

48. It may be that mapping and surveying arose, to some degree, to serve this desire to achieve some measure of a natural holding of land. As Susan Sontag explained, to photograph is to reduce to the literally, physically possessable. See SusAn Sontag, On PHOTOGRAPHY 4 (2001).

Notably, conserved areas may be subject to a wide range of intensive human interventions such as those designed to control invasive species or suppress fires. The distinction may fall, more accurately, between economically productive or extractive land uses such as manufacturing and development, which are valorized by the larger culture, and non-productive or non-yielding land uses, which tend to be derogated by culture, or at best not widely validated.

49. For example, as Thomas Merrill argues, in the context of adverse possession, even while good faith should logically be irrelevant to a determination of adverse possession, courts tend to find a way to prevent bad faith adverse possession. Thomas Merrill, Property Rules, Liability Rules, and Adverse Possession, in Perspectives on Property Law, supra note 25, at 190-91. Merrill argues that courts cannot resist "manipulating" the standard elements of an adverse possession claim to make sure that a bad faith possessor is punished - and to deter others from similar behavior. Id. at 196. 
are those of cultivation, manufacture and development." ${ }^{50}$ Indeed some theories, such as Scrope's elaboration of Blackstone's original theory, suggest that possession is not valid as a property claim unless there is "full and complete utilization" of the property. ${ }^{51}$ Epstein also pointed to this problem, when he criticized first possession theories of property as circular, arguing that " $[t]$ he labor theory is called upon to aid the theory that possession is the root of title; yet it depends for its own success upon the proposition that the possession of self is the root of title to self." ${ }^{52}$

Blackstone worried that "we seem afraid to look back to the means by which [property] was acquired, as if fearful of some defect in our title." ${ }^{, 53}$ I believe this unwillingness to look too closely stems, in part, from the fact that when it comes to real property, possession is imaginative or metaphorical.

This metaphorical nature of possession, particularly when unrecognized, distorts our attempts to theorize property. Assuming a literal meaning of possession has added false legitimacy to the Lockean labor theory through a correlated confound. Failing to recognize the metaphorical nature of our concepts of possession, we have elevated labor by using it as a proxy repeatedly. Indeed, we have focused on labor far more than Locke ever would have.

\section{LOCKE'S PROVISO \& CONTEMPORARY INTERPRETATIONS}

Locke's theory of labor voiced the concerns of his predecessors, such as Gerard Malynes, who in 1622 asked, "Who would till the ground if he hoped not to taste of the crop of it? Surely all would be waste and desolate, if men were to plant and build for everybody, that is nobody." ${ }^{, 4}$ Security of the investment encouraged labor. ${ }^{55}$

The bad faith/adverse possession problem demonstrates that as much as property theory may revolve around possession, possession fails to fully explain how courts adjudicate disputes over rightful ownership. Even when faced with indisputable statutory requirements, courts balk at the primacy of mere possession.

Agreeing with Merrill's conclusion that courts refuse to allow title to transfer when there is bad faith, I would argue that this social ordering by the courts represents our association of bad faith dispossession of property with acts of violence. While there are many reasons we apply legal rules to allow adverse possession, to allow it in bad faith would be to undercut the very reason we protect private property: to deter flagrant dispossession and its concomitant violent acts. As the U.S. Supreme Court has expressed, the common law always views adverse possession as an "act of force." Jackson, 30 U.S. at 438 . This is something the courts must treat carefully as any system of property has a very limited ability to promote the use of force for removal.

50. Rose, supra note 31, at 88.

51. Pat Moloney, Colonisation, Civilisation and Cultivation: Early Victorians' Theories of Property Rights and Sovereignty, in LAND AND FREEDOM, supra note 19, at 23, 31.

52. Epstein, supra note 31, at 1227.

53. 2 William Blackstone, Commentaries 2 (1809).

54. Gerard Malynes, The Ancient Law-Merchant 53 (1622).

55. Id. 
Yet, despite the importance of reaping the benefits of one's work, Locke explicitly limited his theory of private rights to only "where there is enough, and as good left in common for others." "Locke asked for "the industry of the people," which he believed would "[make] plenty of money there without the impoverishing of their neighbours." 57 Locke believed that "every man should have as much as he could make use of," but this was because he could do so "without straining anybody; since there is land enough in the world to suffice double the inhabitants." $" 58$

Locke's formulation thus limited labor where the community's situation would make private claims likely to cause violent conflict. ${ }^{59}$ Without being explicit, Locke references the impoverishing and straining that generate intolerable structural violence. ${ }^{60}$ Such structural circumstances solidify inequalities and prime a society for potentially violent conflicts.

Unfortunately, while no one seems to dispute Locke's limitation of his labor theory to conditions of surplus, Locke's proviso has been treated as no longer relevant-as merely a part of the creation story. ${ }^{61}$ Locke's limitation is indeed a part of the creation story, but it is more than a description of scenery. It is a significant limitation on his theory of labor and one that explicitly emphasizes both the social nature of property and the critical role of property in avoiding violence.

Locke reasoned that, "if either the grass of his enclosure rotted on the ground, or the fruit of his planting perished without gathering and laying up, this part of the earth, notwithstanding his enclosure . . might be the possession of any other. ${ }^{.62}$ In terms of the origins of rightful possession, Locke explained "at the beginning, Cain might take as much ground as he could till, and make it his own land," but he was obligated to "yet leave enough to Abel's sheep." 63

Wastefulness naturally implicates social relationships. When some citizens starve, while others waste resources, violence becomes increasingly likely. ${ }^{64}$ Thus, limiting the labor principle in the situation of wastefulness demonstrates the link between Locke's two foundations of 1) labor and 2) leaving enough for

56. 2 JOHN LOCKE, WORKS OF JOHN LOCKE 27 (1714).

57. Id. at 20 .

58. Id. at 168 .

59. See generally id.

60. See generally id.

61. Leaving Enough Behind, ConST. L. Found., http://www.conlaw.org/Intergenerational-ISL5.htm [https://perma.cc/P9WS-V4QR] (last visited Jan. 2, 2017).

62. Id.

63. Id.

64. As McCaffery explains, "Private waste imposes social harms." Edward J. McCaffery, Must We Have the Right to Waste?, in New Essays in the Legal and Political Theory of ProperTy 76, 77 (Stephen R. Munzer ed., 2001). Even when citizens do not resort to violence, they are always seeking additional and more effective methods of protecting their assets, including optimizing all possible routes to successful litigation that would allow asset recovery. See Benjamin P. Edwards, Disaggregated Classes, 9 VA. L. \& Bus. REV. 305, 306-07 (2015). 
others. ${ }^{65}$

Contemporaries of Locke emphasized the community focus on property rights, suggesting that individuals should not look to unoccupied lands as immediately available, but rather should look to the community for appropriate division of the lands. ${ }^{66}$ Thus, as Thomas Salmon advised, newly discovered land "must not immediately be looked upon as void and waste, so that any person may seize it as his peculiar; but it is lodged in the community prince or state, to whom the adventurers are subject. ${ }^{167}$ This attitude reflects a concern that violence is always a possibility where property is concerned. Salmon admonished his readers that "all nations do insist upon their right to these things. Where is there a pearl fishery open to all foreigners? Or who will permit their oysters to be carried off by strangers if they can oppose it?" ${ }^{98}$ Pufendorf agreed, arguing that citizens should not "lay hands on what they please nor fix themselves as it were by some right in any spot of waste ground they find among us." 69

Indeed, Locke's contemporaries specifically emphasized the communicative nature of possession, and its ability to mediate claims and prevent unnecessary violence. Sprint, for example, explained that property "is by occupation and possession, which is an outward act of the body, quaffs position pedis, and not an inward act of the mind, which cannot be known to others[,] . . . and an outward act of possession warns others to abstain." "70 In this formulation, labor is less linked to its purpose of "reward[ing] work and investment" to its role of preventing violence. Humans are, notably, inclined to violence to protect their investments, particularly when those investments are necessary for basic sustenance.

The Lockean approach to labor of awarding labor pride of place by allowing it to give legitimacy to private property, which is taken from a previously communal system, suggests that the private property owner should be, in all ways, privileged against the community over this particular piece of real property. ${ }^{72}$ The Lockean labor approach does more than privilege labor; it deemphasizes the community's continuing claims to land, or at least to input into

65. See generally 2 LOCKE, supra note 56. Preventing violence was recognized as a cornerstone purpose of property rights. Pufendorf, for example, wrote that the purposes of property are "[1] that thereby the quarrels arising from the original community of ownership are avoided, and [2] that the industry of man is increased." SAMUEL PufEndorf, De JuRE NATURAE ET Gentium 301 (C.H. Oldfather \& W.A. Oldfather trans., Clarendon Press 1934) (1688).

66. See infra notes 80-82 and accompanying text.

67. 1 Thomas Salmon, Modern History, or the Present State of All Nations 728 (3d ed. 1744).

68. Id. at 733 .

69. 3 Samuel Pufendorf, The Law of Nature and Nations 246 (Basil Kennett trans., 4th ed. 1729).

70. JONES, supra note 16 , at 538 .

71. Singer, supra note 6 , at 568 .

72. See generally 2 LockE, supra note 56. 
land use. ${ }^{73}$ Thus, the Lockean approach to labor creates an entirely different set of social relations than a theory of property that centers on dispossession and, therefore, would maintain the importance of the community by recognizing the continually mediating role of property. ${ }^{74}$

Additionally, although modern theories have privileged labor, economic utility does not effectively explain how Anglo-American law has treated ownership claims. Land claims have not been favored solely because they maximized productivity, which indicates that we have treated labor as meaningful, but apparently not meaningful enough to maximize productivity. ${ }^{75}$ If labor is reconsidered from the perspective of dispossession, acknowledging minimal labor investments makes sense. In a context of reasonably abundant land, a person who entered onto real property only two weeks ago and barely settled himself is far less likely to be violent in enforcing his property claim, as compared to someone who has been on real property for years. Labor matters because labor directly correlates with an increased likelihood of violence from property claims.

\section{EXPLANATORY POWERS OF REORIENTING TO DISPOSSESSION}

\section{A. Exclusive Possession as a Foundational Value}

While we talk a great deal about stories of first possession, the truth is that we are not quite so much obsessed with possession as we are obsessed with labor. Natural preferences for first possession are not natural preferences for a position in line, but instead for the investment of labor and connection to sustenance (ideas we have rarely separated very well from possession). More importantly, labor matters instinctively not because of some need to value investments but because labor directly correlates with an increased likelihood of violence arising from property claims.

The more one works upon the land, the more likely the person is to protect the investment, and such behavior is probably evolutionarily favorable. Some notion of property plays a central role in all societies by paving the way for provision for the basic human needs of sustenance. ${ }^{76}$ This link is evident in ancient Roman policy and tradition, which provided that a man might claim public lands, but only "as much . . a as he could cultivate himself.", " Law has repeatedly and explicitly linked property to cultivation and husbandry. ${ }^{78}$

73. Id.

74. Id.

75. Indeed, we know that "individualized property rights are not necessarily the most wealthenhancing form of property." Rose, supra note 11, at 3.

76. Singer, supra note 6.

77. Andrew Lintott, Judicial Reform and Land Reform in the Roman Republic 36 (1992).

78. Stephen Daniels, The Political Iconography of Woodland in Later Georgian Europe, in The Political Iconography of Landscape: Essays on the Symbolic Representation, 
As Carol Rose has argued, Locke's major contribution to the field was his explicit link of property to survival in the most literal sense: "[I]f one cannot literally appropriate those berries and fruits, one will simply die." ${ }^{\prime 79}$ In modern Western contexts, with more families shopping at the grocery store than growing food on the farm, it is easy to lose sight of the traditional link between survival and the use of violence to maintain one's cultivations ${ }^{80}$ The link to sustenance is also visible in Blackstone's discussion of violent biblical conflicts involving possession of wells, which are closely linked with survival, particularly in the arid climates. ${ }^{81}$

As Waldron and Bentham both noted, people simply do not deal well with others taking away something that they have invested in, and thus believe is rightfully "theirs." 82 The sentiment is summarized in the American Revolutionary belief that "a man is a slave if his property can be taken without his consent." 83 The fear of having the fruits of one's labor confiscated is the kind of thing to raise the spirit of violence. As Oliver Wendell Holmes explained, "A thing which you have enjoyed and used as your own for a long time, whether property or an opinion, takes root in your being and cannot be torn away without your resenting the act and trying to defend yourself, however you came by it." ${ }^{84}$ Property is inescapably connected to our need for sustenance, ${ }^{85}$ and this connection may explain our tendency to have strong intuitions about the morality of takings of property ${ }^{86}$ Humans tend to attach to their first investment choices in property and are loathe to change them; a natural inertia keeps existing claims in place as a default - this is particularly true if there is a sense of having invested in that particular property ${ }^{87}$ Human attachment to property has often been compared to

Design and Use of Past Environments 43 (Denis Cosgrove \& Stephen Daniels eds., 1988).

79. Carol M. Rose, Property as Storytelling: Perspectives from Game Theory, Narrative Theory, Feminist Theory, in Perspectives on Property Law, supra note 25, at 28, 31 (emphasis removed).

80. We rarely see such a link between survival and land, except as noted in the work of some modern poverty scholars who are re-introducing the link between land and poverty. See, e.g., Charles Geisler, Land and Poverty in the United States: Insights and Oversights, 71 LAND ECON. 16,16 (1995).

81. 2 BLACKSTONE, supra note 25 , at 48 .

82. Jeremy Waldron, Property, Honesty, and Normative Resilience, in NEW ESSAYS IN THE Legal and Political Theory of Property, supra note 64, at 24. See also Donald J. Kochan, Keepings, 23 N.Y.U. ENV. L.J. 355, 356 (2015) ("Property law has developed based on the presumption that, more often than not, individuals want to keep what they own.").

83. Jennifer Nedelsky, Law, Boundaries, and the Bounded Self, 30 REPRESENTATIONS 162, 163 (1990).

84. Oliver Wendell Holmes, The Path of the Law, 10 HARv. L. REv. 457, 477 (1897).

85. See Singer, supra note 6, at 570-71 (noting that property frequently provides sustenance).

86. See Joseph W. Singer, Property and Social Relations: From Title to Entitlement, in Property and Values: Alternatives to Public and Private Ownership 4 (Charles Geisler \& Gail Daneker eds., 2000).

87. There is an interesting question then that arises about the attachment to land that is often 
animal territoriality. ${ }^{88}$ Why would a person want to surrender either land or an item if there is, as psychologists have argued, "a sense of personal control or competence associated with possession"? ${ }^{89}$

By reconsidering labor in terms of the psychological dynamics of investment rather than maximization of economic utility, one connects directly with physical property's traditional role as a baseline for survival in pre-industrial societies. Property is, as Ely wrote, "the guardian of every other right." ${ }^{90}$ Property takes this unique role because it is a non-violence mediator that establishes a basis for stability, for food security, and peace. Within pre-industrial societies, when relatively little land had been removed from forestation and prepared for cultivation, labor on the land was all the more significant because "the improvement of labor [made] the far greater part of the value." ${ }^{91}$

Displacing labor as the primary justification for first possession rules allows us to recognize that labor is subordinate to managing social conflict. ${ }^{92}$ Labor underpins feelings of fairness, and underlines why first possessors are likely to fight for their territorial claims. ${ }^{93}$ Additionally, labor introduces physical changes onto the land, making visible an occupier's territorial claim. Given the state of the technology of surveying and mapping prior to the nineteenth century, as well as the availability and keeping of records, such visibility was absolutely crucial for providing notification of claims to passersby. ${ }^{94}$

Property laws have not only favored possession, but also favored exclusive possession as a central feature of the concept, thereby placing enormous emphasis on the right to exclude (which might also be thought of as the right to prevent even the most minute of dispossessions).$^{95}$ Notably, exclusivity has been so

observed in rural community. Scholars have commented on this phenomenon before. See Lisa Pruitt, Gender, Geography \& Rural Justice, 23 Berkeley J. GENDER, L. \& Just. 338, 355 (2008) ("Evidence of rural residents' attachment to place is a recurrent finding ...."); Lisa Pruitt, Place Matters: Domestic Violence and Rural Difference, 23 WIS. J.L. GENDER \& SOC'Y 347, 400 ("Rural residents are commonly associated with an attachment to place....").

88. Yi-Fu Tuan, Geopiety: A Theme in Man's Attachment to Nature and to Place, in Geographies of the Mind: Essays in Historical Geosophy (David Lowenthal \& Martyn J. Bowden eds., 1976).

89. Richard Pipes, Human Nature and the Fall of Communism, in PersPeCtives ON PROPERTY LAW, supra note 25, at 45, 51.

90. James W. Ely, The Guardian of Every Other Right: A CONSTitutional History OF Property Rights 26 (1997).

91. LOCKE, supra note 26, at 195.

92. See John William Allen, English Political Thought 1603-1660, at 369-70 (1938).

93. Daniels, supra note 78. In a forthcoming article, Donald Kochan persuasively argues that pride is an overlooked part of this equation and one that can further explain the human attachment to property. Donald J. Kochan, The Symbiosis of Pride \& Property (forthcoming), https://papers.ssrn.com/sol3/papers2.cfm?abstract_id=2891716 [https://perma.cc/JKK9-VY6D] (last visited Feb. 25, 2017).

94. SonTAG, supra note 48.

95. Timothy Earle, Archaeology, Property, and Prehistory, 29 Ann. Rev. Anthropology 
soundly regarded as the central feature of property that social scientists tend to define property as theory which "determines exclusive rights." 96

The right of exclusive possession is "the bedrock of English land law,"97 and a chief import of American property law. In developing legal theory for the new government of the United States, James Madison believed that property entailed "dominion which one man claims and exercises over the external things of the world, in exclusion of every other individual." 98 Madison's theory strongly reflects the influence of Roman law, which had as its central concept the idea of dominium, or the right to full control and to exclude others, ${ }^{99}$ and viewed possession specifically in terms of sole access. ${ }^{100}$ Madison's choice is unsurprising, given that during the colonial era British reliance on Roman law increased because these principles were "legal resources that had some efficacy within the broader supranational community." 101 Property in the newly colonized America succeeded through the denouncing of more communal tribal claims in favor of the fences and single residences of the colonists. ${ }^{102}$

The U.S. Supreme Court has followed Madison's approach, finding that the right to exclude is a "fundamental element of the property right." 103 Theorists J.E. Penner and Thomas Merrill both find that the right to exclude/right to exclusive use is the centerpiece of the concept of property. ${ }^{104}$ The right to exclude is often considered a defining characteristic for the institution of property. ${ }^{105}$

Reframing property theory around non-violence/dispossession explains why exclusion tends to be a central tenant of real property concepts even across disparate legal cultures. Exclusion is central because entry onto property, particularly when unexpected, is a threat and thus a possible precursor to

39, 39-40 (2000).

96. Id.

97. Hunter v. Canary Wharf Ltd., 2 WLR 684, 706B (1997) (Lord Hoffman). With that said, Carol Rose has argued that Blackstone would have seen the right of exclusive possession as an "ideal type rather than a reality." Carol M. Rose, Canons of Property Talk, or, Blackstone's Anxiety, 108 YALE L.J. 601, 604 (1998).

98. James Madison, Property, NAT'L GAzetTe (Mar. 29, 1792), http://presspubs.uchicago.edu/founders/documents/v1ch16s23.html [https://perma.cc/98R3-2CQ9].

99. Joshua Getzler, Roman Ideas of Landownership, in LAND LAW: THEMES AND Perspectives 81-82, (Susan Bright \& John Dewar eds., 1998).

100. Id. at 95. Roman law, however, also included ideas of concurrent ownership of property. David A. Thomas, Why the Public Plundering of Private Property Rights is Still a Very Bad Idea, 41 Real Prop. Prob. \& Tr. J. 25, 36 (2006).

101. Ken Macmillan, Sovereignty and Possession in the English New World 48 (2006).

102. Id. at 121 .

103. Kaiser Aetna v. United States, 444 U.S. 164, 179-80 (1979).

104. J. E. Penner, The Idea of Property in Law 103 (1997); Thomas W. Merrill, Property and the Right to Exclude, 77 NEB. L. REV. 730, 730 (1998).

105. Carol Rose, The Comedy of the Commons: Custom, Commerce, and Inherently Public Property, 53 U. CHI. L. REv. 711, 711 (1986). 
violence. And humans want ways to avoid violence. Like other primates we prefer not to be violent. ${ }^{106}$ Excluding others from the property that we are willing to fight to protect is a method of securing non-violence. And it was this exclusivity that Blackstone seemed to believe so captured the hearts of men. ${ }^{107}$ The first part of Blackstone's sentence is often quoted without the clarifying remainder, which emphasizes "that sole and despotic dominion which one man claims and exercises over the external things of the world, in total exclusion of the right of any other individual in the universe." ${ }^{108}$

\section{B. Reconciling Economics and Communication through the Lens of Dispossession}

Consider, for example, Carol Rose's approach. In a 1988 essay, Rose focused on the "hard-edged" doctrines that we tend to prefer in property law. She acknowledged that economics suggest the more important something is, the more inclined we are toward hard and fast rules, but she also argued that "[w]e establish a system of clear entitlements so that we can barter and trade for what we want instead of fighting." 109 Rose did not explore this idea in depth, however, as her primary focus was on the two types of property rules-(1) clear or strict and (2) muddy or blurred - and their increasing tendency to move toward each other. ${ }^{110}$

Ten years later, Rose revisited the issue in the context of discussing Blackstone and the origins of claims to private property. ${ }^{111}$ She noted, "Permanent claims allowed the 'occupiers' to avoid conflicts with one another and encouraged them to labor on the things to which they now claimed a durable right .... Exclusive dominion is useful because it reduces conflicts and induces productive incentives." 112 Yet, she moved over the connection to violence quickly to focus on the link between established, secure claims and the overall generation of wealth or willingness of occupiers to invest in property. ${ }^{113}$ Indeed, she later questioned whether first-possession rules promote or prevent violence, suggesting

106. There is evidence that primates in general avoid conflict. Frans de Waal, known for his studies of peacemaking habits in primates, explains his theory using an evolutionary argument: conflict avoidance may simply be the only feasible method of long-term existence for a creature that prefers community. See generally Frans B.M. De WaAl, Peacemaking Among Primates (1989).

107. "There is nothing which so generally strikes the imagination, and engages the affections of mankind, as the right of property." 2 BLACKSTONE, supra note 53, at 2.

108. Id.

109. Carol M. Rose, Crystals and Mud in Property Law, 40 Stan. L. Rev. 577, 578 (1988).

110. Id. at 580 ("This paper is about the blurring of clear and distinct property rules with the muddy doctrines of 'maybe or maybe not,' and about the reverse tendency to try to clear up the blur with new crystalline rules.”).

111. Rose, supra note 97.

112. Id. at 606-07.

113. Id. at 607 . 
"[t]he problem is that a first-occupancy principle invites everyone to grab at everything, and everyone winds up fighting with everyone else." ${ }^{114}$ As she later argued, "Blackstone's massive doctrinal sections disclosed very little to remind readers of the reasons of the self-seeking, possibly violent and certainly problematic initial grabs of initial occupancy." 115 But her analysis neglected the context in which this initial land grab took place: an excess of land, when compared with the population, with appealing property nearby that would have weighed heavily against the urge to fight for another's claim.

In her influential 1994 book, Rose re-examined Locke's approach to first possession rules and concludes that what society chose to reward was not so much the labor of cultivation, but more the labor of "speaking clearly and distinctly about one's claims to property." because of its economic utility; clear communication about ownership minimizes waste and maximizes efficiency in the system. ${ }^{117}$ Rose's emphasis was on the economics. ${ }^{118}$ As she said, "Economists have the answer: clear titles facilitate trade and minimize resource-wasting conflict." 119 Rose implicitly favored Bentham's view of property as primarily directed toward wealth and prosperity. ${ }^{120}$

In looking to the question of what determines possession, Rose seems to share my view of the concept of possession as metaphorical; she links possession not to acts of physical holding or control, or even to cultivation and labor, but instead with clear acts or communications of intention. ${ }^{121}$ As she summarizes her point, "The clear-act principle suggests that the common law defines acts of possession as some kind of statement." ${ }^{122}$ More forcefully, she describes, "Possession as the basis of property ownership, then, seems to amount to something like yelling loudly enough to all who may be interested." ${ }^{123}$

Indeed, by investigating the idea of first possession we can discover some truths about the nature of our concept of property, ${ }^{124}$ but we need not necessarily do so by focusing on the value of communication in terms of the economics, primarily referencing wealth and investment as Rose did. A more critical component, and one she briefly mentions, ${ }^{125}$ is communication's role in preventing violent conflicts. This understanding also dovetails with other approaches that focus on the types of labor that create visible changes on the land.

Rose adopted the communication approach because "it correctly draws

114. Id. at 609 .

115. Id. at 611 .

116. Rose, supra note 11 , at 16.

117. Id.

118. $I d$.

119. Id.

120. Id. at 3 .

121. See id.

122. Id. at 13 .

123. Id. at 16 .

124. See id. at 16-20.

125. See id. at 16. 
attention to the intensely social nature of property." ${ }^{26}$ This insight serves us well, but her approach leaves us wanting with its deeply economic approach, which orients her view of social relations primarily toward issues of efficiency and wealth. Refocusing on dispossession/non-violence adopts Rose's insights about the importance of the particular labor of communicating one's territorial claim while offering a better explanation for the primacy of first possession rules than an investment-based economic approach.

Refocusing on dispossession doesn't mean removing economic approaches from the equation. But it does highlight some of the failings of traditional investment-based approaches. First, an approach that privileges an investmentbased economic view of labor and communication fails to satisfy our sense that first possession rules need an explanatory, perhaps even moral, story. ${ }^{127}$ Second, law and economics approaches have favored the rule of first possession, arguing for the rule's efficacy in rewarding labor and promoting active use of resources. ${ }^{128}$ Although many of these arguments may support the idea that a rule of first possession was advantageous, it is difficult to imagine that such ideas were instrumental in establishing such a regime in the first instance in a small society with a limited population and no shortage of land. ${ }^{129}$ Those criticisms aside, however, economic analyses are likely to be consistent with a non-violence or dispossession-based approach to thinking about why labor matters.

An economic argument could be applied to show the value of any rule of property that favored non-violence and avoided the waste of repeated conflicts and property disputes. ${ }^{130}$ Thus, for example, Abraham Bell \& Gideon Parchomovsky have proposed a theory of property based on the idea of

126. Id. at 4 .

127. See Thomas W. Merrill \& Henry E. Smith, The Morality of Property, 48 WM. \& MARY L. REV. 1849, 1850 (2007) (arguing that "no system of property rights can survive unless property ownership is infused with moral significance").

128. Richard Posner, Economic Analysis of Law, in Perspectives on Property Law, supra note 25 , at 54,59 .

129. Although some economists do not explicitly argue that economic motivations were the cause of initial choices in property, others specifically argue the effect on initial choices, implying at least a functional overall social awareness of long-term and large-scale economic impacts. See, e.g., Jeffry M. Netter et al., An Economic Analysis of Adverse Possession Statutes, 6 InT'L REv. L. \& ECON. 217, 217 (1986) (arguing that in choosing limits for adverse possession in statutes, states balanced economic benefits and detriments of uncertainty in title and costs of protecting titles).

130. Admittedly, such sophisticated analyses were not unknown in early civilizations. The early Roman system of property gave signs of a systematic design that maximized the utility of land through time and across regions. See Gardiner, supra note 12, at 124. Yet, Roman law allowed the individual landowner to choose to allow his land to remain waste without penalty. See BRIAN P. OWensby, Empire of LAW AND Indian Justice in Colonial MeXico 94 (2008) (explaining the Roman approach while comparing and contrasting notions of possession of pre-conquest indigenous societies and the Spanish crown). However, with the fall of Rome, these insights were largely lost as other legal systems developed. Few were recovered until they influenced the development of civil law many centuries later. See Gardiner, supra note 12, at 125. 
organizing property rules to favor "the value inherent in stable ownership." 131

While Bell and Parchomovsky's theory makes sense based on utilitarian economics, a property system that promotes stable ownership is also likely to promote non-violence - at least in its initial setting of distribution with land in abundance. Such an understanding is also an intuitive one and can be understood in the short-term as an on-the-ground view that might have influenced the adoption of private property regimes.

\section{Understanding the Origins of Private Property}

A central debate over the origins of private property (and the justice of continuing distributions and regimes) is the question of consent to the institution itself. In the 1992 decision of Lucas v. South Carolina Coastal Council, the U.S. Supreme Court gestured to the idea of consent to a social contract by referencing the "long recognized" "understandings of our citizens," or more generally, the idea of an unwritten "historical compact" supporting the current property regime. ${ }^{132}$ Yet in a strongly worded dissent, Justice Blackmun wrote that "[i]t is not clear from the Court's opinion where our 'historical compact' or 'citizens' understanding' comes from, but it does not appear to be history." 133

Epstein has described that " $[t]$ he fundamental objection against both theories of first possession and theories of original common ownership is that neither is powerful enough to bind non-consenting individuals." 134 A theory refocused on dispossession/non-violence does have such power. Such a theory centralizes communal well-being and retains it in a position of prominence such that private property rights can be adjusted periodically in the face of new threats such as climate change.

Whether or not there was ever an explicit consent to a social contract, adaptations to suit survival logically would have favored non-violence. Hugo Grotius' understanding of property favored the idea of occupation without disturbance as a necessity to survival — and he saw property as furthering that goal of survival, or more specifically as a derivative of that right to survival. ${ }^{135}$ Grotius' formulation is also consistent with the idea that survival is maximized in a situation of non-violence.

Refocusing on dispossession/non-violence affirms the foundational link between property and law. Such a link has been long recognized by legal theorists, such as Richard Baxter who, writing in 1664, linked "parliaments and property," noting that without them "any security of estate or liberty or life"

131. Abraham Bell \& Gideon Parchomovsky, A Theory of Property, 90 CoRnell L. Rev. 531, 538 (2005).

132. 505 U.S. $1003,1027-28$ (1992).

133. Id. at 1055-56 (Blackmun, J., dissenting).

134. Epstein, supra note 31, at 1240.

135. Knud Haakonssen, Hugo Grotius and the History of Political Thought, reprinted in Grotius, Pufendorf and Modern Natural Law 35, 36 (Knud Haakonssen ed., 1999). 
would be destroyed. ${ }^{136}$ In this formulation, both primarily exist-indeed coexist- to manage social conflict. ${ }^{137}$

In a community with a low population, with more land readily available, a rule of first possession based on rightful continued possession would have fostered peaceful relations and possibly an even greater likelihood of overall survival. If, then, as Guido Calabresi and A. Douglas Melamed suggest, property is the result of a "collective decision," "138 the decision might be less consent to the notion of private property in and of itself, and more one of consent to the concept as a method of achieving another end: non-violence.

Richard Epstein's account of the origins of property rights is consistent with this account as well. Epstein argued that in pre-history, rights of first possession prevailed, but then suffered because of encroachments against these accepted rights of ownership. ${ }^{139}$ Epstein argued that people created governments precisely because they found that such institutions were necessary to keep private property rights secure from would-be violators. ${ }^{140}$ Although Epstein's argument moves swiftly beyond the first possession rule to the implications for later governmental infringement on property rights, his historical account emphasizes the critical problem at the point of property right origins: the hostilities that resulted when one person entered upon land occupied by another and claimed the fruits of the other's labors. ${ }^{141}$ Although Epstein may be correct that government was necessary to enforce a system of first possession ownership, his account is compatible with an understanding of the origins of first possession rules in a system of social relationships structuring itself to prevent violence-just as his next evolutionary step of government suggests. ${ }^{142}$

A focus on non-violence and dispossession also explains the intuitive and cross-cultural appeal of first possession rules. Scholars such as Sugden argue that there are natural impulses to respect first possession. ${ }^{143}$ Sugden describes:

Another car is approaching the bridge from the other side. It reaches the bridge before you do and begins to cross. Do you stop and allow the other car to cross, or continue on in the expectation that the other driver will see you coming and reverse? My observation is that most drivers recognize a convention that the first car on the bridge has the right of way. ${ }^{144}$

Although there are certain conveniences and economies to this type of respect for

136. AlLEN, supra note 92 , at 40.

137. Id.

138. Guido Calabresi \& A. Douglas Melamed, Property Rules, Liability Rules, and Inalienability: One View of the Cathedral, 85 HARV. L. REV. 1089, 1092 (1972).

139. EPSTEIN, supra note 30, at 10-15.

140. Id. at 13 .

141. Id. at 10-15.

142. Id. at 11 .

143. Sugden, supra note 27, at 172.

144. Id. 
others, as an instinct it may also reflect our desire to avoid conflict, particularly conflicts that may escalate to violence.

\section{CONCLUSION}

Wesley Hohfeld re-conceptualized property rights in the twentieth century by arguing that the central function of property was not to order the relationship between an individual and an area of land, but rather to order social relationships. ${ }^{145}$ Similarly, Singer, ${ }^{146}$ Munzer,${ }^{147}$ and Rose ${ }^{148}$ reformulated property as a set of social relations. Harold Demsetz described property rights as:

[I]nstrument[s] of society [that] derive their significance from the fact that they help a man form those expectations which he can reasonably hold in his dealings with others. These expectations find expression in laws, customs and mores of a society. ${ }^{149}$

In many ways, there is nothing new about the social relations approach to property. Blackstone's famous formulation of our affection for property contains words that belie the social nature of property—words such as hold, dominate, and control. ${ }^{150}$

Yet, despite our willingness to understand property in terms of social relations, our emphasis on possession has continually obscured the social relations of property in favor of the individual's private claim. Courts may in passing note that property manages social relationships, but in practice courts focus on possession and individual rights, rather than limiting private rights in favor of the greater good of the community. The result is that whenever communities push back against private rights by attempting, for example, to regulate land uses more stringently, the community effectively faces a serious uphill battle.

The courts have focused on possession, which they operationalized as an investment-based approach to labor. This approach diverges from the thinking of the many theorists who supported a labor approach during our founding era-theorists who would have thought of labor not just in terms of investment, but also in terms of managing human conflict.

Thinking of labor in terms of investment rather than in terms of what a person

145. Wesley Newcomb Hohfeld, Fundamental Legal Conceptions as Applied in Judicial Reasoning, 26 YALE L.J. 710, 721 (1917). Although Hohfeld's thesis has been highly influential, there are dissenters. See, e.g., PENNER, supra note 104, at 2 (arguing that property is best understood as "the right to a thing").

146. Singer, supra note 86 , at 8 .

147. Stephen R. Munzer, Property as Social Relations, in New Essays IN THE Legal AND Political TheOry of Property, supra note 64, at 36.

148. Rose, supra note 11, at 4.

149. Harold Demsetz, Toward a Theory of Property Rights, in The ECONOMICs OF PROPERTY Rights 31 (Eirik G. Furubotn \& Svetozar Pejovich eds., 1974).

150. See 2 Blackstone, supra note 25 , at $45-52$. 
is willing to go to arms over undermines the critical role of property in maintaining peaceful social arrangements. Thinking about labor in terms of nonviolence rather than just investments, and thinking about dispossession rather than possession reframes our rhetoric and recovers the social function of property as a mediator with the ability to prevent violence.

Similarly, such a reformulation opens us to recognizing how, in Rousseau's formulation, a property regime may, particularly over the long-term, generate inequality through the right to exclude. ${ }^{151}$ Recognizing that labor and vested interests must, at a point, yield to the need to mediate and stabilize, legal systems could acknowledge a point at which inequality becomes so pervasive that our protection of property owners, particularly against externalities of other land uses, must change to accommodate social well-being.

151. Jean Jacques Rousseau, The Second Discourse 159-60 (1964). 